\title{
DUTIES, POWERS AND RESPONSIBILITIES OF THE EXPERT ENGINEER OF TECHNICAL ASSISTANTS IN JUDICIAL DECISIONS WITH THE CONSTRUCTION INDUSTRIES
}

\author{
Ilidiane Corrêia de Oliveira ${ }^{1}$, Fabio Junio Rodrigues da Silva ${ }^{2}$, Adriano Silvestre Fernandes ${ }^{3}$, Carlos \\ Eduardo de Carvalho Costa ${ }^{4}$ and Antonio Estanislau Sanches ${ }^{5}$
}

\author{
1, 2. 3,4 Institute of Higher Education Blauro Cardoso de Mattos - FASERRA. Manaus-Amazonas, Brazil. \\ ${ }^{5}$ Galileo Institute of Technology and Education of the Amazon - ITEGAM. Manaus-Amazonas, Brazil.
}

Email: lidia_oliveira21@hotmail.com, f.fabiojunio28@gmail.com, silvestrekalu@gmail.com, ecarloscarvalho39@gmail.com, novo.sanches@gmail.com

\section{Received: Oct 28 2019}

Accepted: Jan $23^{\text {th }}, 2020$

Published: February $10^{\text {th }}, 2020$

Copyright C2016 by authors and Galileo Institute of Technology and Education of the Amazon (ITEGAM).

This work is licensed under the Creative Commons Attribution International License (CC BY 4.0).

https://creativecommons.org/licen ses/by/4.0/

\begin{abstract}
This work has as its central theme: "The contribution of the expert in the labor court decisions", where it begins to point out that in the work related issues, such as dangerousness and unhealthiness, the expert examinations will be performed by a single expert. For its work consists of a set of technical-scientific procedures designed to bring to the decision-making body the necessary evidence to support the just settlement of the dispute or the finding of a fact. In response to the problem of this study consisting of the following question: What is the contribution of the expert in labor court decisions with a construction company? This study highlights the role of expertise rests in the search for truthfulness linked to the facts that require appreciation of the Occupational Safety sector, which is one of the fundamentals that should be prioritized in the work. In this regard, this study also highlights that the expertise in the Civil Construction industries must be technologically rigorous and closely correlated with the expert records, translating into formal truth, which will assist in the magistrate's conviction regarding the objects in dispute. In this line of reasoning it is understood that expertise can be considered as a product under development, as it is in constant transformation.
\end{abstract}

Keywords: Judicial Expertise, Report, Expert.

\section{INTRODUCTION}

With each passing day engineering is striving to add the use of new technologies, mainly due to the globalized scenario in which we are inserted that increasingly strengthens the competitiveness among civil construction organizations. In addition to the need to reinvent itself at all times, through new courses, the engineering professional should be able to answer for the company's management, regarding project compatibility, quality, deadline, among others.

Faced with this scenario the engineering professional tries to walk the fine line between success or error in the execution of their work activities, with risks of technical disputes.

Irregularities can occur in the execution stage, in the acquisition of land, in the choice of materials, and even due to the poor qualification of the workforce selected to perform the services. In addition, the lack of maintenance and preventive correction by those responsible for the assets, compromise the infrastructure and endangers society in various environments, causing numerous questions [1].

In this scenario emerges the role of the Expert Engineer, which was regulated after the validity of the new Civil Procedure Code. The Expert Engineer's work consists of a set of technicalscientific procedures designed to bring to the decision-making body the necessary evidence to support the fair settlement of the dispute or the finding of fact, by means of an expert report and / or opinion, in accordance with the legal and professional standards, and specific legislation as appropriate.

In this regard, the issues of the work performed by the Engineer are currently discussed in the field of professional, organizational and governmental action. Expertise in the field of work is a service provided by the Engineer as an expert to assist decision makers: federal and state judges and members of arbitral tribunals. Thus, expertise in the field of construction plays a 
relevant role, especially when it comes to the functionality of its reports, reports and opinion [2].

The expertise among the other areas of Engineering also aims to control the assets of the entities, in the judicial scope that will be judged to decide on certain situations existing in disputes between the parties. Engineering expertise is "the manner of clarifying, demonstrating or proving equity information that is of interest to the parties through the Expert Report" [3].

It is also emphasized that in general the Construction Industries have been receiving sanctions and penalties when they do not bother to respect the current legislation, either for noncompliance or recklessness of the responsible sector. Within this context, this study is justified in contributing, from the theoretical point of view, the activities of engineering expertise by differentiating "right" and "wrong" in the development of their organizational activities, so the expert engineer faces many situations. who demand from him choices, which aim to resolve the doubts raised by the Judgment, and before that involve himself and others, who impose decisions and consequences and in most can benefit one and harm the other [4].

In this sense, the Expert Engineer "is in charge of the exercise of expertise, and should consider the effects for the benefit of society, providing well-being to all who have an interest in the controversy." The process of expertise in court decisions is exercised by a qualified professional, highlighting his contribution in an appropriate manner in the exercise of his profession, as well as the standards of procedure of the class measured by ethics [5].

\section{DEVELOPMENT}

The Judicial Expertise is that originated from the Magistrate's need to elucidate facts of a case, to clarify and issue a decision, based on this context, this study points out that the expert is a special instrument of scientific, technical, evidence, proof or demonstration. of the veracity of situations, things or facts through the reports [6].

Regarding the meaning of the report, it has that "it consists of an expert document, documenting the facts, the operations performed and the duly substantiated conclusions reached by the expert of the expert" [8]. In this understanding, it is pointed out that the expert report is "a pronouncement or manifestation of an expert, that is, what he understands about a question or several, which are submitted for its consideration" [3].

Another instrument of the expertise is the opinion, which consists of "the work of the technical assistant, who does not lose the characteristics of the report", according to this understanding it is pointed out that the difference between the report and the opinion is in the professional who performs it [1], as follows:

The expert report and the judicial expert opinion shall contain at least the following items:

a) identification of the process and the parties;

b) synthesis of the object of expertise;

c) methodology adopted for expert work;

d) identification of the steps taken;

e) transcription and answer to the questions: for the expert report;

f) transcription and answer to the questions: for the accounting expert opinion, where there is disagreement, transcription of the questions, answers formulated by the accountant expert and the answers and comments of the assistant accountant expert;

g) conclusion;

h) attachments; i) Appendices;

j) signature of the expert: will indicate his professional category of Engineer and his registration number in the Regional Council of Engineering and Agronomy (CREA), proven by Declaration of Professional Qualification - DHP. The use of digital certification is allowed, in accordance with current legislation and standards established by the Brazilian Public Key Infrastructure ICP - Brazil.

However, it is noteworthy that "the opinion is broader than the expert report, because it aims to answer the questions, and, if necessary, to oppose opinion about the Expert's answers contained in the report" [7]. Still within this context, it is emphasized that the structure of the judicial report issued by the Expert Engineer, should be presented as follows: in legal size paper, without letterhead, edited in computer, with observation of conventional margins for filing and that its structure meets at least the following set of information:

1) Identification: records, district, sticks, names of the parties, the Expert and the assistants;

2) Summary of the case: summary of the case, in the content related to the objective of the expert;

3) Objective of the expert: extracted from the order of appointment (if in the instructional phase) or the sentence (if in the execution phase);

4) Guidelines: regulatory foundations of expert work (CPC, LTP, NBC, Laws directly related to the object in dispute);

5) Due diligence: expert practices used;

6) Questions / answers: transcript of the question as it is in the case file, followed by the reasoned and commented answer;

7) Closing: conclusive summary, inform, communications with assistants, number of sheets and attachments, place, date, signature;

8) List of attachments: Sheet after the closing term.

In light of what has already been stated, it should also be noted that the expert report is a formal technical piece that presents the result of an expert's report, and it must contain everything that had been subject to expert examination. In this sense, it is commented that the expert Engineer is characterized as a professional who in the exercise of his activities must unceasingly seek the truth in relation to a certain fact and send as evidence to users who use accounting expertise as a basis for decision making [8].

This is because the need for judicial expertise occurs when there is a lack of facts practiced by one of the parties, in this sense, stresses that, "the expertise is necessary to verify situations of administrative and accounting irregularities, resulting from technical imperfections, professional negligence. Technical errors and bookkeeping, infractions, simulations, tampering and fraud, in order to seek the culprits for such acts and their degree of responsibility for such" [2].

In response to the objective of this study, which is to describe the contribution of expertise in court decisions, it is briefly elucidated that expertise in a construction site is a set of experiences that are linked to what they represented (company and worker) in their trajectories. and expressed themselves in the judicial disputes in which they participated.

\section{MATERIALS AND METHODS}

In this work the research developed was of a qualitative nature, since the data were qualified as to their relevance. 
Throughout the research were analyzed the theories of legal researchers, who relate engineering with expertise, which constitute the theoretical framework of this study. Bibliographic archives, available on the Internet, media, companies, public data, libraries and others were employed.

The present work was based on the study of the new Code of Civil Procedure (CPC 2015), Section II - Of the Expert: the attributions and duties of the engineer as subject of the process, and in Section X - The Expert Evidence: the description of the steps in knowledge process. The results were analyzed seeking to highlight the research objectives through bibliographical analysis.

\section{STUDY APPLICATION}

For a better understanding, this category of study begins by describing the meaning of judicial expertise, where it is emphasized that the expression expertise comes from the Latin expert, which in its meaning means knowledge, skill, knowledge. A diligence performed or performed by experts, in a generic way for any kind of expertise, since there are several types of expertise all with their own particularities. Also, in questions that may occur disputes in which the expert must resolve the dispute, or will subsidize the decision Judge. To this end, he will seek information necessary to give confidence and full support for the preparation of his expert report, given that it must be prepared by a legally qualified and qualified accounting expert, that this information will count a lot for the Judge's decision making [ 9].

Regarding this understanding, this study points out that judicial expertise is a technical demonstration of the truth of facts or situations. Expertise in a corner of works, both judicial, extrajudicial and arbitral, is the exclusive competence of the expert engineer registered in CREA (Regional Council of Engineering and Agronomy), because they have distinct characteristics from each other in which allows to observe their characteristics. and the mode of action of each expert. Based on the Fur studies [4] this study highlights some types of accounting expertise with:

- JUDICIAL EXPERTISE: is performed within the procedural procedures of the judiciary, by determination, requirement or need of its active agents, and is processed according to specific legal rules, in which the judge may or may not have the parties present, but professional To perform this function need not be entered into or have employment ties with any entity, it must be clear and objective, because the expertise made will have evidence to the judge's decision.

- SEMIJUDICIAL EXPERTISE: is that carried out within the state institutional apparatus, but outside the judiciary, having as its main objective to be evidence in institutional orders, and can be subdivided into three groups: the Police, Parliamentary and administrative, also they serve as the burden of judicial proof before the Judge, as they are subject to legal and regimental rules.

EXTRAJUDICIAL EXPERTISE: Extrajudicial expertise is that performed outside the State Powers and the Judiciary Power, since it is born from both individuals and legal entities, as they can be supported by discriminatory, supporting and demonstrative statements.

- ARBITRAL EXPERTISE: is held in the arbitration court - a decision-making body created by the will of the parties, not being framed in any of the above by its special characteristics of acting partially as if judicial and extrajudicial were. It may be subdivided into probative and decisive if it is intended to function as evidence of arbitral judgment, as a subsidiary of the arbitrator's conviction, or is arbitration itself, that is, its active agent functions as the arbitrator of the dispute itself.
The fact is that regardless of the classification of the skill, the method of execution of the skill is basically analytical, not dispensing details whenever necessary. Therefore one must then: identify the objective well; competently plan the work; perform work based on unambiguous, full and fully reliable evidence; be very careful about the conclusion and only issue it after you are absolutely sure about the results; conclude in a clear, precise and unambiguous manner [2].

In light of this caveat, it is noted that in recent years there has been a strong interest in expertise at the construction site in the judicial areas, where the image of the expert Engineer is compulsory, making it highly relevant for performing the calculations and mission of opinion. which will serve to support the decision of the Court.

\section{RESULTS AND DISCUSSIONS}

\section{- The Expert Engineer}

According to the Code of Civil Procedure, The Expert Engineer is the professional regularly registered in CREA (Regional Council of Engineering and Agronomy), who carries out the expert activity on a personal basis, and must be profoundly aware, by his qualities and experiences, of the subject. expert. Within this context, it is further emphasized that the expert Engineer is the one designated by the judge in judicial expertise; contractor is the one who acts in extrajudicial expertise; and chosen is the one who exercises his function in arbitral expertise.

Among the main technical-professional competences to be performed by the expert Engineer, it should be noted initially that the technical competence presupposes that the expert maintain an adequate level of knowledge of the engineering area, occupational safety techniques, the legislation related to the profession and those applicable to the expert activity, being permanently updated through qualification, training, continuing education and specialization programs. To this end, it must demonstrate the ability to:

a) Research, examine, analyze, synthesize and substantiate the evidence in the expert report and expert opinion.

b) Performing their work with respect for equity means that the accountant and the assistant accountant must act with equal rights, adopting the legal and technical precepts inherent to the profession.

According to the new CPC/2015 in art. 156, the judge shall be assisted by an expert when evidence of the fact depends on technical or scientific knowledge thus provided:

Paragraph 1. Experts shall be appointed from among the legally qualified professionals and the technical or scientific organs duly registered in a register maintained by the court to which the judge is bound.

Paragraph 2. For the formation of the register, the courts shall carry out public consultation, by means of disclosure on the world wide web or in widely circulated newspapers, in addition to direct consultation with universities, class councils, the Public Prosecution Service, the Defender's Office. And the Brazilian Bar Association, to appoint interested professionals or technical bodies.

Paragraph 3. The courts shall carry out periodic evaluations and reassessments to maintain the register, taking into consideration the professional training, the updating of knowledge and the experience of the interested experts.

Paragraph 4. For verification of any impediment or reason for suspicion, pursuant to Arts. 148 and 467, the technical or scientific body appointed to carry out the expertise will inform the 
judge of the names and qualification data of the professionals who will participate in the activity.

Paragraph 5. In the place where there is not entered in the register made available by the court, the appointment of the expert is free choice by the judge and shall be the responsibility of a professional or technical or scientific body with proven knowledge to carry out the expertise.

The CPC/2015 brought a great and advantageous innovation for all that is the Consensual Expertise according to art. 471 , in which the parties may, by mutual agreement, choose the expert, indicating him upon request to the judge, provided that:

I - Be fully capable;

II - The cause may be resolved by self-composition.

Paragraph 1. The parties, when choosing the expert, must already appoint their respective technical assistants to accompany the realization of the expertise, which will take place at a previously announced date and place.

Paragraph 2. The expert and the technical assistants shall deliver, respectively, a report and opinions within a time limit set by the judge.

Paragraph 3. Consensual expertise shall, for all intents and purposes, replace that which would be performed by an expert appointed by the judge.

Expert work begins when, when verifying its need, the magistrate admits or requires the production of the accounting expert evidence and, consequently, appoints the accountant, who may be substituted. After the appointment of the expert, the judge shall grant a period of ten days for the parties to express their views and presentation of the questions (CPC, article 422) and five days for the appointment of technical assistants of the parties (CPC, article 421, paragraph 1). After the deadline, the expert will be informed of his appointment by subpoena, whereby he is summoned to find out about the expert matter assigned to him. This is where the effective involvement of the expert with a given expert process begins.

Upon becoming aware of his appointment, the expert should take charge of the case file and be responsible for his zeal. He must then present the provisional fee proposal, made by his own petition filed with the notary. Once formalized to the petition. The judge will open views to the parties to comment on the fees, agreeing or not with their value. In the event of disagreement, the judge will ask the expert to comment on the allegations, after which he can decide whether to replace it or simply arbitrate the amount, and the expert will accept or give up the work. If there is agreement, the judge will dispatch the petition granting

\section{CONCLUSIONS}

The present work had as main objective to analyze the contribution of the Expert Report in the judicial decisions. From this perspective, it is firstly emphasized that accounting expertise must be technologically rigorous and closely correlated with expert accounting records, translating into formal truth, which will assist in convincing the magistrate of the objects in dispute. In this line of reasoning it is understood that the expertise in a construction site can be considered as a product under development, because it is constantly changing. In addition, regarding the standardization of the expert report with the judiciary, there are several guidelines for performing the work of the Expert Engineer. In response to the problem of this study which consists of the following question: What is the contribution of the expert in the labor court decisions with the construction companies? This study highlights the role of expertise rests in the pursuit of truthfulness linked to facts that require factual appraisal, and this pursuit is one of the fundamentals that should be prioritized in the work of both the Expert Engineer and the Assistant Expert Engineer. Thus, the expertise will have its importance, as it will bring to the decision-making body the necessary evidence to support the just settlement of the dispute and will be fulfilling its role in protecting society. In the final analysis, it is pointed out that the main function of the expertise is to generate true information, so it must be composed taking into account the greater responsibility and caution of the professionals involved.

\section{REFERENCES}

[1] Gerolla, Giovanny. Carreira: Perito em Engenharia. São Paulo: Revista Téchne, edição 182. 2011.

[2] Medeiros Junior, Joaquim da Rocha. Perícias de engenharia em edifícios, peritos e seus paradigmas e desafios dos novos tempos. Dissertação (Mestrado em Tecnologia e Gestão na Produção de Edifícios) - Escola Politécnica da Universidade de São Paulo. São Paulo: Universidade de São Paulo, 2002.

[3] Danquimaia, Vinícius Leandro das Chagas. Influência da perícia na tomada de decisão nos casos da Justiça Trabalhista. Brasília: UNICEUB, 2011.

[4] Peleias, Ivam Ricardo [et al.]. O papel da Perícia no canteiro de obras. Educ. rev. [online]. 2011, vol.27, n.3, pp. 79-108.

[5] Reiter, Iane de Brito. Perícia trabalhista. [Monografia]. Lajeado, UNIVATES, 2014.

[6] Neves Junior, I.J. [et al.]. Perícia na justiça do trabalho. In: XXXV encontro do ANPAD. Rio de Janeiro, 2011.

[7] Magalhães, Antonio de Deus Farias. O papel da perícia no processo cível e trabalhista: o valor informacional da engenharia para o sistema judiciário. São Paulo: Atlas, 2018.

[8] Silva, Pollyana Alves da. A perícia no judiciário. In: XXXV encontro do ANPAD. Rio de Janeiro, 2016.

[9] Ornelas, Martinho Mauricio gomes de. Perícia Contábil. 5 ed. São Paulo, 2011. 